\title{
Toxicity of the phenolic extract from jabuticabeira (Myrciaria cauliflora (Mart.) $O$. Berg) fruit skins on Spodoptera frugiperda
}

\author{
Ana Paula C. Alves ${ }^{1 *}$, Angelita D. Corrêa ${ }^{1}$, Dejane S. Alves ${ }^{1}$, Adelir A. Saczk ${ }^{1}$, Jéssica B.R. Lino ${ }^{1}$, \\ and Geraldo A. Carvalho ${ }^{1}$
}

Fall armyworm, Spodoptera frugiperda J.E. Smith, 1797 (Lepidoptera: Noctuidae) is the main pest of maize, besides attacking sorghum and cotton crops. The control of this pest has been accomplished mainly with the use of synthetic insecticides but, due to the growing concern about the environment and food quality, phenolic compounds have shown their potential for the biological control of this insect. Thus, the objective of the present study was to evaluate the efficiency of the extract of jabuticabeira, Myrciaria cauliflora [Mart.] O. Berg (Myrtaceae) fruit skin flour in the control of S. frugiperda. Skins of $M$. cauliflora Sabará genotype were dried at $45^{\circ} \mathrm{C}$ in a forced air oven. In order to obtain the extract, $1.0 \mathrm{~g}$ flour was mixed with $10 \mathrm{~mL}$ acetone: water solution $(7: 3 \mathrm{v} / \mathrm{v})$. Forty-eight-hour-old $S$. frugiperda caterpillars were placed in glass tubes with an artificial diet containing the extract at concentrations of 0,250, 500, 1000, and $2000 \mathrm{mg} \mathrm{L}^{-1}$. The extract, in which the phenolic compounds gallic acid, gallocatechin, catechin, epicatechin, ellagic acid, and salicylic acid were identified at a concentration of $2000 \mathrm{mg} \mathrm{L}^{-1}$, in average, increased mortality rates by $150 \%$ in the larval stage, duration of larval stages by $60 \%$, and pupal by $17 \%$, and decreased amount of females by $55 \%$. On the other hand, the extract at 1000 $\mathrm{mg} \mathrm{L}^{-1}$ only increased duration of larval period by $24 \%$. It was concluded that the extract is harmful to this insect, probably due to the presence of phenolic compounds.

Key words: Botanical insecticide, fall armyworm, natural product, Mirtaceae.

\section{INTRODUCTION}

The caterpillar Spodoptera frugiperda (Lepidoptera: Noctuidae) is a phytophagous and cosmopolitan insect, widely distributed in North and South America, and causes damage in various crops, including corn, sorghum, cotton, and several grasses (Múrua et al., 2009).

The control of this pest has been performed mainly with the use of synthetic insecticides, which cause side effects to the environment, promote the selection of resistant insect populations (Busato et al., 2006), and cause concern about food quality effects, have encouraged studies of new control techniques (Estrela et al., 2006; Oliveira et al., 2006; Santiago et al., 2008). Many plants are sources of natural substances that can be used in pest control, and are an alternative to the indiscriminate use of pesticides (Shin-Foon and Yu-Tong, 1993).

Among the secondary metabolites involved in plant defense against insects, there are subclasses of phenolic compounds, including flavonoids and tannins, which are known to cause a decrease in insect growth and

${ }^{1}$ Universidade Federal de Lavras, Departamento de Química, PO box 3037, CEP 37200-000 Lavras, Brasil.

*Corresponding author (anapaula.quimica@hotmail.com).

Received: 23 September 2013.

Accepted: 2 April 2014.

doi:10.4067/S0718-58392014000200011 survival (Schaller, 2008). Tannins form complexes with the digestive enzymes in the intestine of insects, causing a decrease in the efficiency of protein digestion, and eventually slow growth (Schoonhoven et al., 2005).

Gallo et al. (2006) reported up to $86 \%$ mortality of $S$. frugiperda larvae when fed artificial diets containing phenolic compounds isolated from Vitex polygama Cham (Verbenaceae) and Siphoneugena densiflora Berg (Myrtaceae). Tirelli et al. (2010) found an increase in the duration of larval and pupal stages of S. frugiperda due to the effect of tannins in the stem bark of several forest species, on, besides decrease of about $30 \%$ in pupal weight and $41 \%$ in larvae survival.

Jabuticabeira (Myrciaria cauliflora [Mart.] O. Berg) fruit skins are especially rich in phenolic compounds, up

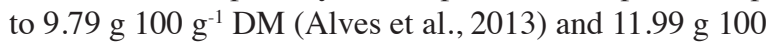
$\mathrm{g}^{-1} \mathrm{DM}$ (Lima et al., 2008) in Sabará genotype. Among the phenolic compounds found in jabuticabeira fruit skins, the anthocyanins cyanidin 3-glucoside and delphinidin 3-glucoside were identified (Lima et al., 2011). These skins, which represent up to $43 \%$ of the fruit (Lima et al., 2008), are considered residue and, when discarded, carry secondary metabolites of great value due to their potential applications as insecticides and/or agrochemicals. Therefore, the objective of this study was to evaluate the effect of the extract of jabuticabeira fruit skin flour as a source of an alternative low toxicity and biodegradable 
natural insecticide against $S$. frugiperda, and to offer a suitable use for this residue.

\section{MATERIAL AND METHODS}

\section{Collection and processing of botanical material}

Mature fruit of jabuticabeira (Myrciaria cauliflora [Mart.] O. Berg), Sabará genotype, were hand-picked in the morning of 17 November 2011, on São José do Ismeril Farm, in the municipality of Coqueiral $\left(21^{\circ} 11^{\prime} 14\right.$ " S, $45^{\circ} 27^{\prime} 2$ " W; $823 \mathrm{~m}$ a.s.1.), in a region near Lavras, Minas Gerais, Brazil. The local climate, according to the Köppen's classification, is Cwa (mild and rainy summer, with moderate temperature, annual average below $21^{\circ} \mathrm{C}$ ). The average annual rainfall and relative humidity are $1500 \mathrm{~mm}$ and $70 \%$, respectively (Emater, 2002).

The healthy fruits were washed in tap water and sanitized with a sodium hypochlorite solution $(200 \mathrm{mg}$ $\mathrm{kg}^{-1}$ ) by immersion for $10 \mathrm{~min}$. They were then pressed to remove pulp, and skins were dried in a forced air oven at $45{ }^{\circ} \mathrm{C}$ until constant weight. After drying, skins were ground and the obtained flour was stored at room temperature in flasks tightly sealed and protected from light.

\section{Extraction}

To obtain the extract, $1.0 \mathrm{~g}$ of fruit skin flour (JFSF) was mixed with $10 \mathrm{~mL}$ of acetone:water $(7: 3 \mathrm{v} / \mathrm{v})$ solution. This mixture was kept $2 \mathrm{~h}$ at room temperature and filtered through glass wool, and then $10 \mathrm{~mL}$ of the acetone:water solution were added to the residue (Agostini-Costa et al., 2003). The residue was discarded and the liquid phases were combined and concentrated on a rotary evaporator until complete evaporation of acetone, adjusting volume to $4.0 \mathrm{~mL}$ when the material was intended for chromatography. When used for the bioassay, after evaporation of acetone, the material was frozen and lyophilized. The extraction was replicated three times.

\section{Identification and quantification of phenolic compounds}

The phenolic standards used were gallic acid, gallocatechin, 3,4-dihydroxybenzene, catechin, chlorogenic acid, epigallocatechin, vanillic acid, epicatechin, syringic acid, p-coumaric acid, ferulic acid, m-coumaric acid, o-coumaric acid, resveratrol, ellagic acid, and salicylic acid (all from Sigma-Aldrich, St. Louis, Missouri, USA). The stock standard solutions were prepared in dimethyl sulfoxide and/or methanol (Merck, Darmstadt, Germany) in a concentration range of 0.10 to $118.78 \mathrm{mg} \mathrm{L}^{-1}$. Acetic acid and methanol (Merck) were used in the preparation of the mobile phase and ultrapure water was obtained from Milli-Q ${ }^{\circledR}$ system (Millipore, Billerica, Massachusetts, USA).

The equipment used was an HPLC (Agilent 1100 Series, Agilent Technologies, Waldbronn, Germany), equipped with a high pressure binary pump (model G1311A), an ALS autosampler and a diode array detector (DAD), and the best response was obtained at a $280 \mathrm{~nm}$ wavelength. The extract and standards were separated on an Ascentis C18 column ( $25 \mathrm{~cm} \times 4.6 \mathrm{~mm}, 5 \mu \mathrm{m}$, Agilent $)$, attached to a Supelguard Ascentis C18 pre-column $(2 \mathrm{~cm}$ $\times 4.0 \mathrm{~mm}, 5 \mu \mathrm{m}$ ).

The mobile phase was composed of $2 \%$ acetic acid (A) and methanol:water:acetic acid (70:28:2 v/v/v) (B). Analyze were performed in a total time of $65 \mathrm{~min}$ at $15{ }^{\circ} \mathrm{C}$ in a gradient-type system: $100 \%$ solvent $\mathrm{A}$ from 0.01 to $5 \mathrm{~min}$; $70 \%$ solvent A from 5 to $25 \mathrm{~min}$; $60 \%$ solvent A from 25 to $43 \mathrm{~min} ; 55 \%$ solvent A from 43 to 50 min and $0 \%$ solvent $\mathrm{A}$ for $10 \mathrm{~min}$ until the end of the run. Solvent A was increased to $100 \%$, seeking to maintain a balanced column. The flux used in all analyzes was 1.0 $\mathrm{mL} \min ^{-1}$ and the injection volume was $20 \mu \mathrm{L}$.

The JFSF extract and standards were filtered through a $0.45-\mu \mathrm{m}$ nylon membrane (Millipore $\AA$, Billerica, Massachusetts, USA) and directly injected into the chromatographic system in three replicates. Phenolic compounds in the extract were identified by comparison with retention times of standards. Quantification was performed by the construction of analytical curves.

\section{Bioassay with $S$. frugiperda larvae}

For the bioassay, the lyophilized extract was solubilized in distilled water and incorporated into the artificial diet at 250, 500, 1000, and $2000 \mathrm{mg} \mathrm{L}^{-1}$.

The experimental design was completely randomized, with 60 replicates per treatment, and in the control treatment only water was incorporated into the diet. The experimental unit consisted of a glass tube $(8.0 \mathrm{~cm}$ high $\times$ $2.0 \mathrm{~cm}$ wide $)$ with a piece of $\operatorname{diet}(1.5 \mathrm{~cm} \times 1.5 \mathrm{~cm})$ plus the extract, where a 48-h-old $S$. frugiperda caterpillar, which was previously fed an artificial diet free of any extract, was inoculated. The experiment was conducted at $25 \pm 2{ }^{\circ} \mathrm{C}, 70 \pm 10 \% \mathrm{RH}$, and a $12: 12 \mathrm{~h}$ photoperiod.

Larval mortality was evaluated daily until pupation. The following biological characteristics were also evaluated: duration of larval stage, pupal weight, duration of pupal stage, and sex ratio of specimens. At adult emergence, couples were placed separately in PVC cages $(10 \mathrm{~cm} \times 10$ $\mathrm{cm}$ ), fed with $10 \%$ honey solution. Insect longevity and oviposition were evaluated daily, until death.

\section{Statistical analysis}

Data on pupal weight, sex ratio, number of oviposition and eggs were subjected to one way ANOVA and, when significant, treatment means were compared by the Tukey test at $\mathrm{p}<0.05$ (PROC GLM; SAS Institute, 2008). Larval mortality and duration of larval and pupal stages were also subjected to one way ANOVA and, when significant, a regression analysis was performed $(\mathrm{p}<0.05)$ depending on the concentration of the extract (PROC REG; SAS Institute, 2008). 
Data on male and female longevity were subjected to survival analysis, using the non-parametric procedure LIFETEST (SAS Institute, 2008). This procedure allows the estimation of survival curves obtained by KaplanMeier estimators, generated from the proportion of surviving insects, from the beginning until the end of the bioassay.

\section{RESULTS AND DISCUSSION}

Several phenolic compounds were identified in the extract (mg $100 \mathrm{~g}^{-1}$ extract): gallic acid (52.00), gallocatechin (27.20), catechin (50.46), epicatechin (145.47), ellagic acid (35.44) and salicylic acid (133.44); gallocatechin, catechin and epicatechin are monomers of condensed tannins (Figure 1). The highest content was presented by epicatechin (Table 1), followed by salicylic acid. It is possible to verify the presence of several other not identified peaks, but they are possibly other phenolic compounds. Lima et al. (2011) identified the anthocyanic phenolics cyanidin 3-glucoside and delphinidin 3-glucoside, however using another extragent.

Gallic and ellagic acids are constituents of hydrolysable tannins, which are defined as esters of gallic and ellagic acids; on the other hand, condensed tannins are oligomers and polymers formed by the polycondensation of two or more flavonoid units and have a great biological significance for their strong interactions with metallic ions and macromolecules, such as polysaccharides, besides

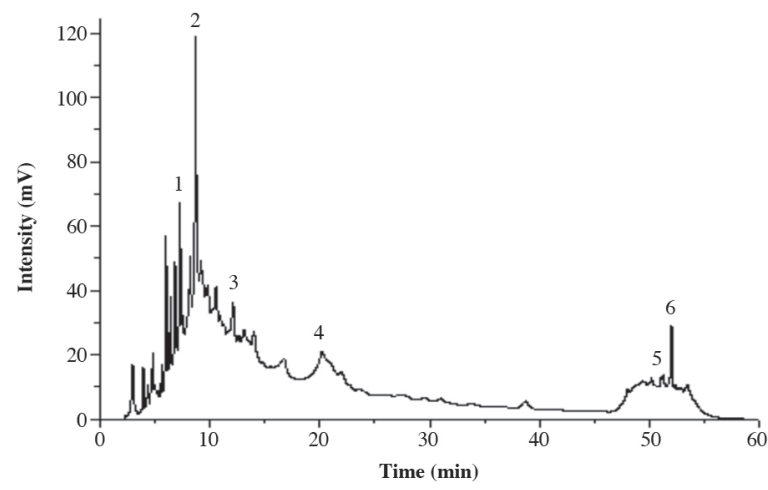

Figure 1. Chromatogram of the jabuticabeira fruit skin flour extract. Identification of peaks: 1: gallic acid, 2: gallocatechin, 3: catechin, 4: epicatechin, 5: ellagic acid, and 6: salicylic acid.

Table 1. Contents of phenolic compounds in jabuticabeira fruit skin extracts added to the artificial diet of Spodoptera frugiperda at different concentrations.

\begin{tabular}{lcccc}
\hline \multirow{2}{*}{$\begin{array}{l}\text { Phenolic } \\
\text { compound }\end{array}$} & 250 & 500 & 1000 & 2000 \\
\cline { 2 - 5 } & $0.13 \pm 0.01$ & $0.26 \pm 0.01$ & $0.52 \pm 0.01$ & $1.04 \pm 0.01$ \\
Gallic acid & $0.14 \pm 0.00$ & $0.28 \pm 0.00$ & $0.56 \pm 0.00$ \\
Gallocatechin & $0.07 \pm 0.00$ & $0.52 \pm 0.02$ & $1.04 \pm 0.02$ \\
Catechin & $0.13 \pm 0.02$ & $0.26 \pm 0.02$ & $0.52 \pm 0.02$ & $2.88 \pm 0.03$ \\
Epicatechin & $0.36 \pm 0.03$ & $0.72 \pm 0.03$ & $1.44 \pm 0.03$ & $\left.2.03 \mathrm{~m} \mathrm{~L}^{-1}\right)$ \\
Ellagic acid & $0.09 \pm 0.01$ & $0.18 \pm 0.01$ & $0.36 \pm 0.01$ & $0.72 \pm 0.01$ \\
Salicylic acid & $0.33 \pm 0.04$ & $0.66 \pm 0.04$ & $1.32 \pm 0.04$ & $2.64 \pm 0.04$
\end{tabular}

Data are the mean of three replicates \pm standard deviation. presenting the ability to form soluble complexes with alkaloids, gelatin, and various proteins. This ability to interact with proteins makes tannins very toxic to insects, fungi, and bacteria (Simões et al., 2001).

When diets containing extracts were consumed by $S$. frugiperda, the extract at $2000 \mathrm{mg} \mathrm{L}^{-1}$ increased mortality of this noctuid during larval stage, but were not affected at lower concentrations (Figure 2).

This result was probably due to the presence of phenolic compounds in the extract, such as hydrolysable tannins which can significantly reduce insect survival and growth, since they inactivate digestive enzymes and create a tannin-protein complex that is difficult to digest (Mello and Silva-Filho, 2002); or catechin that shows higher toxicity to insects that tannins, although it has low affinity for proteins (Monteiro et al., 2005). Gallo et al. (2006) also observed inhibition of larval growth of $S$. frugiperda as a result of the activity of condensed tannins from extracts of Siphoneugena densiflora Berg (Myrtaceae).

The prolongation of the larval phase observed for caterpillars fed diets containing 1000 and $2000 \mathrm{mg} \mathrm{L}^{-1}$ (Figure 2) was possibly due to the presence of phenolic substances that are toxic to the insect, such as gallic acid, which acts as an antifeedant for S. frugiperda larvae (Urrea-Bulla et al., 2004). A longer duration of the larval stage is an advantage in field, since the insects will be prone to predators' attack for a longer time. This result confirms the ones found by Tirelli et al. (2010), who also found effects of tannin fractions of the stem bark on this pest.
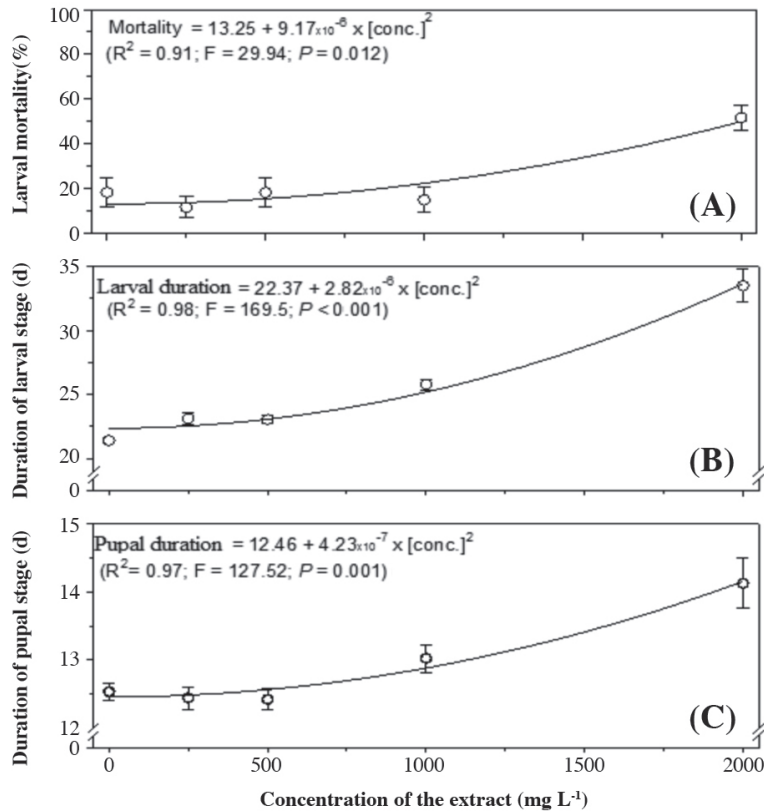

Figure 2. Regression of larval mortality (A), duration of larval (B), and pupal stages (C) of Spodoptera frugiperda for different concentrations of jabuticabeira fruit skin flour extract. 
It was observed that the treatment with $2000 \mathrm{mg} \mathrm{L}^{-1}$ of extract extended the pupal stage of $S$. frugiperda, while pupal weight was not reduced by any treatment (Figure 2). According to Tanzubil and McCaffery (1990), the slow growth of the insect without a reduction in pupal weight, as occurred with insects treated with the phenolic JFSF extract, was possibly caused by low doses of toxic phenolic substances, which are able to inhibit growth, but not their diet. The prolongation of the larval stage of insects caused by the ingestion of natural products has been reported in the literature. Nomura and Itioka (2002) observed an increase in the duration of larval and pupal stages, as well as in larval mortality, and a reduction of adult emergence from the application of synthetic tannins on artificial diets of Spodoptera litura (Fabricius, 1775) (Lepidoptera: Noctuidae), and found that the reduction in larval growth was proportional to the concentration of the substance ingested.

In general, it was found that, although caterpillars were normally fed, the food may have remained in their intestine for a longer time, so that there could be a higher nutrient assimilation. According to Reynolds et al. (1985), Manduca sexta (Linnaeus, 1763) (Lepidoptera: Sphingidae) caterpillars can optimize the retention time of food in the intestine, maximizing the absolute rate of nutrient absorption.

Regarding pupal weight $(\mathrm{F} 4 ; 224=1.4 ; \mathrm{P}=0.235)$, number of oviposition $(\mathrm{F} 4 ; 33=1.49 ; \mathrm{P}=0.226)$ and of eggs $(\mathrm{F} 4 ; 33=2.38 ; \mathrm{P}=0.071)$, negative effects of these extracts on these biological characteristics were not observed (Table 2).

Regarding the longevity of adult males and females (Figure 3), no significant differences were found. Adults began to emerge from the eleventh day, and the last ones died on the thirty-fifth day; there was no significant difference of the treatments concerning survival of males and/or females.

It was possible to observe a significant difference in the sex ratio of adults, which came from caterpillars fed the diet containing $500 \mathrm{mg} \mathrm{L}^{-1}$ extract, with the highest number of females, differing only from adults treated with $2000 \mathrm{mg} \mathrm{L}^{-1}$, which presented the highest amount of males (Table 3). This decrease in the number of females is important, since they are responsible for oviposition, yielding new specimens.

Table 2. Pupal weight, number of ovipositions, and number of eggs of Spodoptera frugiperda from caterpillars fed on a diet supplemented with the extracts.

\begin{tabular}{lccc}
\hline Treatments & $\begin{array}{c}\text { Pupal } \\
\text { weight }\end{array}$ & $\begin{array}{c}\text { Number of } \\
\text { ovipositions }\end{array}$ & $\begin{array}{c}\text { Number } \\
\text { of eggs }\end{array}$ \\
\hline $\mathrm{mg} \mathrm{L}^{-1}$ & $\mathrm{~g}$ & & \\
0 & $0.30 \pm 0.03$ & $10.42 \pm 3.62$ & $2.982 .63 \pm 617$ \\
250 & $0.30 \pm 0.03$ & $10.14 \pm 2.27$ & $2.316 .38 \pm 716$ \\
500 & $0.31 \pm 0.03$ & $10.57 \pm 2.70$ & $2.663 .38 \pm 308$ \\
1000 & $0.31 \pm 0.03$ & $11.88 \pm 2.17$ & $2.341 .75 \pm 395$ \\
2000 & $0.30 \pm 0.04$ & $8.50 \pm 2.88$ & $1.940 .50 \pm 731$ \\
\hline
\end{tabular}

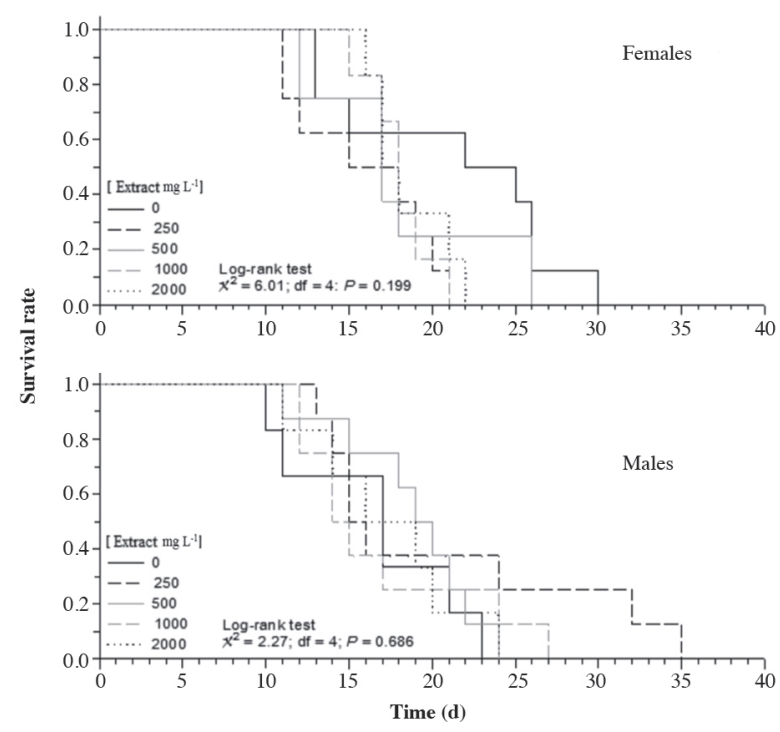

Figure 3. Survival curves for females and males of Spodoptera frugiperda, over time, coming from caterpillars fed on the diet containing the jabuticabeira fruit skin flour extract.

Table 3. Sex ratio of Spodoptera frugiperda from caterpillars fed on a diet supplemented with the extracts.

\begin{tabular}{lll}
\hline Extract & $\mathrm{n}$ & Sex ratio \\
\hline $\mathrm{mg} \mathrm{L}^{-1}$ & & \\
0 & 48 & $0.48 \mathrm{ab}$ \\
250 & 45 & $0.51 \mathrm{ab}$ \\
500 & 45 & $0.73 \mathrm{a}$ \\
1000 & 44 & $0.43 \mathrm{ab}$ \\
2000 & 24 & $0.29 \mathrm{~b}$ \\
\hline -value $^{* *}$ & 0.005 \\
\hline
\end{tabular}

"P-value of ANOVA. ${ }^{* *}$ Means followed by the same letter do not differ according to Tukey test $(\mathrm{P}>0.05)$.

\section{CONCLUSIONS}

The jabuticabeira fruit skin flour extract, in which phenolic compounds gallic acid, gallocatechin, catechin, epicatechin, ellagic acid, and salicylic acid were identified at a concentration of $2000 \mathrm{mg} \mathrm{L}^{-1}$, was toxic to Spodoptera frugiperda. It caused an increase in larval mortality, as well as in larval and pupal stages, and a decrease in the amount of females.

At the concentration of $1000 \mathrm{mg} \mathrm{L}^{-1}$, the extract caused an increase only in the duration of the larval stage of $S$. frugiperda.

\section{ACKNOWLEDGEMENTS}

The authors would like to thank Fundação de Amparo à Pesquisa do Estado de Minas Gerais (FAPEMIG), Conselho Nacional de Desenvolvimento Científico e Tecnológico (CNPq) and Coordenação de Aperfeiçoamento de Pessoal de Nível Superior (CAPES) for the financial support. 


\section{LITERATURE CITED}

Agostini-Costa, T.S., A. Lima, e M.V. Lima. 2003. Determinação de tanino em pedúnculo de caju: método da vanilina versus método do butanol ácido. Química Nova 26:763-765.

Alves, A.P.C., A.D. Corrêa, A.C.M. Pinheiro, and F.C. Oliveira. 2013. Flour and anthocyanin extracts of jaboticaba skins used as a natural dye in yogurt. International Journal of Food Science and Technology 48:2007-2013.

Busato, G.R., A.D. Grützmacher, M.S. Garcia, M.J. Zotti, S.D. Nörnberg, T.R. Magalhães, et al. 2006. Susceptibilidade de lagartas dos biótipos milho e arroz de Spodoptera frugiperda (J.E. Smith, 1797) (Lepidoptera: Noctuidae) a inseticidas com diferentes modos de ação. Ciência Rural 36:15-20.

Emater. 2002. Área de proteção ambiental do Município de Coqueiral. Empresa de Assistência Técnica e Extensão Rural (Emater), Unidade de Consultoria e Projetos, Belo Horizonte, Minas Gerais, Brasil.

Estrela, J.L.V., M. Fazolin, V. Catani, M.R. Alécio, e M.S. Lima. 2006. Toxicidade de óleos essenciais de Piper aduncum e Piper hispidinervum em Sitophilus zeamais. Pesquisa Agropecuária Brasileira 41:217-222

Gallo, M.B.C., W.C. Rocha, U.S. Cunha, F.A. Diogo, F.C. Silva, P.C. Vieira, et al. 2006. Bioactivity of extracts and isolated compounds from Vitex polygama (Verbenaceae) and Siphoneugena densiflora (Myrtaceae) against Spodoptera frugiperda (Lepidoptera: Noctuidae). Pest Management Science 62:1072-1081.

Lima, A.J.B., A.D. Corrêa, A.P.C. Alves, C.M.P. Abreu, e A.M. Dantas-Barros. 2008. Caracterização química da fruta jabuticaba (M. cauliflora Berg) e de suas frações. Archivos Latinoamericanos de Nutrición 58:416-421.

Lima, A.J.B., A.D. Corrêa, A.A. Saczk, M.P. Martins, and R.O. Castilho. 2011. Anthocyanins, pigment stability and antioxidant activity in jabuticaba [Myrciaria cauliflora (Mart.) O. Berg]. Revista Brasileira de Fruticultura 33:877-887.

Mello, M.O., and M.C. Silva-Filho. 2002. Plant-insect interactions: an evolutionary arms race between two distinct defense mechanisms. Brazilian Journal of Plant Physiology 14:71-81.

Monteiro, J.M., U.P. Albuquerque, E.L. Araújo, e E.L.C. Amorim. 2005. Taninos: uma abordagem da química à ecologia. Química Nova 28:892-896.

Múrua, M.G., J. Molina-Ochoa, and P. Fidalgo. 2009. Natural distribution of parasitoids of larvae of the fall armyworm, Spodoptera frugiperda, in Argentina. Journal Insect Science 9:117.
Nomura, M., and T. Itioka. 2002. Effects of synthesized tannin on the growth and survival of a generalist herbivorous insect, the common cutworm, Spodoptera litura Fabricius (Lepidoptera: Noctuidae). Applied Entomology and Zoology 37:285-289.

Oliveira, A.M., P.B. Maracajá, E.T. Diniz Filho, e P.C.F. Linhares. 2006. Controle biológico de pragas em cultivos comerciais como alternativa ao uso de agrotóxicos. Revista Verde 1:1-9.

Reynolds, S.E., S.F. Nottingham, and A.E. Stephens. 1985. Food and water economy and its relation to growth in fifth-instar larvae of the tobacco hornworm, Manduca sexta. Journal of Insect Physiology 31:119-127.

Santiago, G.P., L.E.M. Pádua, P.R.R. Silva, E.M.S. Carvalho, e C.B. Maia. 2008. Efeitos de extratos de plantas na biologia de Spodoptera frugiperda (J.E. Smith, 1797) (Lepidoptera: Noctuidae) mantida em dieta artificial. Ciência e Agrotecnologia 32:792-796.

SAS Institute. 2008. SAS/STAT User's guide v.8. SAS Institute, Cary, North Carolina, USA.

Schaller, A. 2008. Induced plant resistance to herbivory. p. 189-208 In Bernards, M.A., and L. Bastrup-Spohr (eds.) Phenypropanoid metabolism induced by wounding and insect herbivory. Springer, New York, USA.

Schoonhoven, L.M., J.J.A. van Loon, and M. Dicke. 2005. Plants as insect food: not the ideal. Insect plant biology. 115 p. Oxford University, New York, USA.

Shin-Foon, C., and Q. Yu-Tong. 1993. Experiments on the application of botanical insecticides for the control of diamondback moth in South China. Journal Applied Entomology 116:479-486.

Simões, C.M.O., E.P. Schenkel, G. Gosmann, J.C.P. Mello, L.A Mentz, e P.R. Petrovick. 2001. Farmacognosia: da planta ao medicamento. Editora da Universidade Federal do Rio Grande do Sul, Porto Alegre, Brasil.

Tanzubil, P.B., and A.R. McCaffery. 1990. Effects of azadirachtin and aqueous Neem seed extracts on survival, growth and development of the African armyworm, Spodoptera exempta. Crop Protection 9:383-386.

Tirelli, A.A., D.S. Alves, G.A. Carvalho, R.R Sâmia, S.S. Brum, e M.C. Guerreiro. 2010. Efeito de frações tânicas sobre parâmetros biológicos e nutricionais de Spodoptera frugiperda (Lepidoptera: Noctuidae). Ciência e Agrotecnologia 34:1417-1424.

Urrea-Bulla, A., M.M. Suárez, and B. Moreno-Murillo. 2004. Biological activity of phenolic compounds from Alchornea glandulosa. Fitoterapia 75:392-394. 